\title{
Configurações da melancolia em Eichendorff
}

\author{
NATHASChKa MARTINIUK - USP
}
O olhar do acidioso pousa obsessivamente sobre a janela e, com a fantasia, finge ser a imagem de alguém que vem visitá-lo; ao rangido da porta, ergue-se em pé; ouve uma voz, e corre para pôr-se à janela para olhar; contudo não desce para a estrada, mas volta a sentar-se onde estava antes, entorpecido e quase empalidecido.

$\overline{\text { Sancti Nili, De octo spiritibus }}$ malitiae.

O poema Sehnsucht, cujo título pode ser tanto traduzido por saudade (de algo do passado), quanto por anseio (de algo ainda por vir), narra cenas do que poderia ser lembranças do eu lírico ou imagens de um futuro ansiado por este. Na primeira estrofe, a atmosfera é aparentemente bastante agradável, as estrelas brilham resplandecentes, e o eu lírico observa sozinho, da janela, a 
paisagem, e deseja poder penetrar na magnífica noite de verão (In der prächtigen Sommernacht, v.8). Nas estrofes seguintes vemos uma cena de contentamento, jovens alegres cantam e dessa forma evocam um lugar idílico.

O poema adquire outra dimensão quando percebemos que o título manifesta a falta de algo por parte do eu lírico, o qual não pode participar da cena a não ser como observador que sente saudades do passado (ou que anseia por esse momento).

Para apresentar as configurações da melancolia nesse poema, será preciso retomar alguns conceitos históricos sobre o tema. Para atingir os objetivos deste artigo, não será exposto exaustivamente o tema da melancolia, suas diversas definições e imensa tradição na cultura ao longo da história, mas se faz necessário apontar duas questões fundamentais para a análise, a saber, a perda e a contemplação.

Como ouro as estrelas brilhavam, Solitário, eu estava à janela, Quando ouvi a trompa do postilhão Ecoando ao longe na tranquila terra. 5.Por todo meu corpo, o coração ardia, Pois eu pensava em minha solidão: Ah, quem ao meu lado viajaria, na suntuosa noite de verão!

Dois jovens amigos caminhavam, 10. Subindo a encosta da grande colina, Eu ouvia da janela o que cantavam No passeio pela estrada tranquila: Cantigas de enormes precipícios, 
Onde a floresta murmura suave, 15. De nascentes, que desde os abismos

Afloram em meio à noite selvagem.

Cantavam de estátuas de pedra, Em jardins por sobre a rocha nua, Crescendo selvagens na penumbra 20. Como palácios ao brilho da lua, Onde as moças à janela escutam, O alaúde despertando em canção $\mathrm{E}$ fontes adormecidas murmuram Na suntuosa noite de verão. (Eichendorff in Adorno, 2003, p. 114-115)

Melancolia, segundo Hipócrates, a quem a primeira definição é atribuída, é uma tristeza e medo de longa duração. Constantinus Africanus, autor árabe medieval, amplia a definição de Hipócrates com a ideia de perda. Os melancólicos seriam, então, aqueles "que perderam seus filhos e amigos mais queridos, ou algo precioso que não puderam restaurar":

Os acidentes que a partir dela [da melancolia] sucedem na alma parecem ser o medo e a tristeza. Ambos são péssimos porque confundem a alma. Com efeito, a definição de tristeza é a perda do muito intensamente amado. O medo é a suspeita de que algo ocasionará dano. (Africanus apud Ginszburg, 2001, p. 103)

Walter Benjamin, em "Origem do drama barroco alemão", menciona, a partir dos estudos do historiador de arte Karl Gieh- 
low (1863-1913) sobre a famosa obra de Albrecht Dürer (14711528), Melencolia I, que o melancólico tem a disposição para a contemplação. A imagem retratada na gravura de Dürer, uma espécie de "figura andrógina e alada, híbrido de homem, mulher e anjo" (Kehl, 2009, p. 69), seria a imagem exemplar do homem contemplativo: a obra do artista alemão representa o estado melancólico, diante do qual "o saber técnico e racional, vinculado à geometria e aos instrumentos de trabalho, é colocado no mundo 'do luto e do fracasso humanos"' (Ginzburg, 2001, p. 112). Perdida em divagações e "cercada por instrumentos científicos de mensuração e conhecimento do universo: um compasso, uma ampulheta que marca a passagem implacável do tempo, mapas do mundo que se ampliara a partir dos descobrimentos, formas geométricas, um grande livro sobre os joelhos e, às suas costas, um quadrado mágico onde se inscreve a esperança de sintetizar a harmonia do universo", essa figura não dirige "seu olhar ensimesmado" "a nada nem a nenhum desses objetos; antes sinaliza o abatimento ante a incapacidade de (tudo) saber" (Kehl, 2009, p. 70). A posição dessa personagem perdida em divagações também é emblemática do melancólico: sua cabeça está apoiada por uma de suas mãos, e seus olhos estão, muitas vezes, voltados em direção à terra.

De acordo com Klibansky, Panofsky e Saxl, na obra Saturno e Melancolia, para os escritores da Idade Média e do Renascimento a melancolia teria relação com o planeta Saturno, este sendo o verdadeiro culpado pelo caráter e destino desventurado do melancólico. A estreita relação entre os humores e seus respectivos planetas foi estabelecida por escritores árabes do século IX, na chamada doutrina das influências astrais.

Segundo Karl Giehlow, a meditação do melancólico é compre- 
endida na perspectiva de Saturno, que

como o planeta mais alto e o mais afastado da vida cotidiana, responsável por toda contemplação profunda, convoca a alma para a vida interior, afastando-a das exterioridades, leva-a a sucumbir cada vez mais alto e enfim inspira-lhe um saber superior e o dom profético. (Benjamin, 1984, p. 172)

Tanto a imagem da contemplação é expressa no poema, o eu lírico está à janela, olhando para fora, para algo além do ambiente doméstico, quanto a imagem da falta, da perda. Seu canto, poético, é solitário e descreve o que poderia ser uma lembrança do próprio eu lírico. Lembrança essa que surge a partir da contemplação de algo além do ambiente privado. $\mathrm{O}$ som da trompa do postilhão em meio à silenciosa terra faz com que o eu lírico relembre, ou deseje, algo, o qual é cantado logo em seguida.

Além da contemplação e da perda, a melancolia é marcada por um dualismo intenso. Em seus estudos sobre o tema, Jaime Ginzburg escreve que o "comportamento dual do melancólico se deve [...] à coexistência paradoxal de dois instintos do sujeito - a afirmação de si, em busca de uma ascensão, e a renúncia à existência."(Ginzburg, 2001, p. 113). Esse dado remete-nos à questão da ametria do temperamento melancólico, exposta por Hubert Tellenbach ${ }^{1}$ (1914-1994), segundo o qual o melancólico procura transcender seus próprios limites, mas se frustra, pois sua precariedade o impede. A finitude o inquieta, pois sua consciência aspira ao Absoluto, mas as limitações são inevitáveis. Não podendo ser definida de maneira unívoca e exata, a

${ }^{1}$ C.f. Ginzburg, 1997, p. 57-58. 
condição melancólica é descrita por alguns estudiosos como um estado "de passagem" (Pot apud Ginzburg, 1997, p. 58). A instabilidade de transição, como por exemplo, "o mover-se de uma faixa etária a outra, da maturidade à velhice, é melancólico." (Ginzburg, 1997, p. 59).

No poema Sehnsucht, se assumirmos que o canto do eu lírico é expressão de uma lembrança, a irrecuperabilidade do passado rememorado marca a constituição da melancolia. Ademais, apesar da perda de um passado descrito como idílico, a meditação sobre o objeto perdido intensifica o estado melancólico, pois ao contemplar o grandioso, o sujeito acometido pela bile negra recusa seu impotente estado limitado ${ }^{2}$. Essa dualidade, contemplar o inalcançável, é nada menos que a resistência da cerceada condição humana.

A segunda e terceira estrofes representam ou descrevem o canto dos dois jovens companheiros (Zwei junge Gesellen, v.9). Seu canto é harmonioso e é recitado no tempo verbal presente, ou seja, pode-se dizer que o lugar sobre o qual a canção é entoada é o lugar da perfeição, no qual não é preciso se preocupar com o futuro, nem com o passado, predomina-se o atemporal. A esse lugar ideal, cujo tempo é suspenso, são conferidos atributos harmoniosos e amenos, como por exemplo, "Wo die Wälder rauschen so sacht," (Onde as florestas sussurram tão mansamente; v.14); "Palästen im Mondenschein,/ Wo die Mädchen am Fenster lauschen," (Palácios à luz do luar,/ onde as moças, à janela, escutam; v.20 e 21). "Wann der Lauten Klang erwacht,/ Und die Brunnen verschlafen rauschen" (Quando o alaúde desperta em canção/ E fontes adormecidas murmuram; v.22 e 23). A cena idílica descrita é, contudo, apenas concretizada na própria

${ }^{2}$ cf. J. Ginzburg, 1997, p. 62. 
canção dos dois amigos, que é, por sua vez, rememorada pelo eu lírico, o qual entoa, ele mesmo uma canção - o próprio poema que lemos. O poema enuncia o canto que o eu lírico rememora.

Pode-se, portanto, identificar no poema três camadas ou, fazendo uma equivalência com quadros, três molduras: (1) na primeira moldura está o eu lírico entoando a canção - o poema Sehnsucht; (2) na segunda moldura temos a imagem narrada pelo eu lírico, ou seja, os jovens caminhando, subindo pela colina, passeando pela estrada tranquila (segunda estrofe); (3) na terceira moldura temos a canção entoada pelos dois amigos (final da segunda estrofe, v.13-16, e terceira estrofe). Além disso, o canto dos dois amigos remete o leitor a lugares misteriosos: "Cantigas de enormes precipícios/ Onde a floresta murmura suave", "Estatuas de mármore", "Palácios ao brilho da lua", "Fontes adormecidas murmuram". Percebe-se aí uma oposição entre o espaço cantado e o espaço no qual eles cantam (retornando, assim, à segunda moldura: uma estrada tranquila). O entorno da segunda moldura, por sua vez, se opõe ao ambiente da primeira: enquanto os jovens caminham pela natureza, espaço externo, o eu lírico entoa sua canção de um espaço privado, um quarto.

Apenas através do canto o eu lírico pode reviver esse tempo saudoso, do qual ele mesmo pode ter participado - ele poderia ter sido um dos dois companheiros que vagavam pelas colinas. O objeto de desejo é alcançado unicamente na própria canção proferida. As diversas sobreposições de molduras, no entanto, revelam que há uma distância entre o eu lírico (primeira moldura) e o seu desejo (terceira moldura). A forma do poema mostra que essa distância não pode ser suplantada. O movimento que se vê é o da busca, a qual, no poema Sehnsucht, configura-se como canção, em suas diversas molduras. O poema é, em si, e isso 
nos remete ao título, uma constante busca. Como mencionado anteriormente, Sehnsucht pode referir-se tanto ao passado como ao futuro. Nesse poema, especificamente, é possível entendê-lo como um anseio pelo retorno da temporalidade cantada, à qual é congregado um espaço, ambos sentidos pelo eu lírico como ideais.

A atmosfera cantada e criada pelos dois jovens poderia ser também interpretada como algo além de uma lembrança, como um tempo primordial, no qual a falta não se dá. De qualquer forma, a harmonia reinante na canção recitada no poema é uma denúncia da ausência desse momento suntuoso - sendo um poema cíclico (último verso faz retornar à primeira estrofe), relembramos que o eu lírico está sozinho, seu coração arde com chama intensa e seu desejo é por uma companhia.

Outro paralelismo entre a canção entoada pelos dois amigos (terceira estrofe) e a canção entoada pelo eu lírico (primeira estrofe) é a imagem da janela. Na primeira estrofe, o eu lírico está à janela, e ao ouvir o som da trompa do postilhão ecoando ao longe é despertado nele algo que o remete para além do ambiente em que está. A imagem dos dois jovens passeando, na segunda estrofe, é evocada a partir do som ouvido na primeira estrofe, a trompa do postilhão. Na terceira estrofe, por sua vez, agora já dentro da canção dos dois amigos, as moças estão também à janela, e agora são elas que ouvem o som do alaúde que desperta em canção, assim como o som do murmurar das fontes adormecidas.

A música desperta algo que está sempre além e não pode ser capturado. Contudo, apenas a partir dela as imagens são construídas - tanto a lembrança do momento em que os dois jovens estão vagando na colina, bem como a imagem da última estrofe, 
onde as moças escutam à janela o som do alaúde. É importante observar que, para a lírica de Eichendorff, a música parece ter especial importância. Em seu conhecido poema "Wünschelrute" (Forquilha), pode-se perceber que mais do que uma mera característica de seus versos, acordar a música de todos os objetos é tarefa de sua poética:

Dorme uma canção em todas as coisas, que lá sonham e continuam a sonhar, E o mundo soergue a cantar, Se a palavra mágica tu encontrar. ${ }^{3}$

A palavra mágica, a poesia, revela-se em Sehnsucht em forma de canção, a qual é executada pelo eu lírico, para o leitor, desde a primeira estrofe. Apesar da irreparável perda, o eu lírico contempla com anelo ausência do que foi perdido. A contemplação de algo inalcançável consistiria "em uma espécie de evasão com relação ao mundo concreto" (Ginzburg, 1997, p. 73). Segundo Mario Praz, "[n]aquilo que é inefável [...] consiste-se a essência da romanticidade" (Praz, 1996, p. 34). Enquanto os escritores do classicismo "defendiam a necessidade de síntese" (Ginzburg, 1997, p. 72), os românticos buscavam "a expressão do inefável", pois estariam se aproximando dos "contornos problemáticos" e das "zonas irracionais". Em Sehnsucht, esse lugar idílico, inatingível, expresso apenas por seus fragmentos, despertados ou emergidos a partir da canção (ou se quisermos, da palavra mágica) dos dois amigos (enormes precipícios, as nascentes, estátuas de mármore, jardins por sobre a rocha nua, palácios),

3 "Schläft ein Lied in allen Dingen,/ die da träumen fort und fort,/ Und die Welt fängt an zu singen,/ Triffst du nur das Zauberwort". 
representa aqui uma parte do todo, apontando para algo maior que causa a Sehnsucht do eu lírico. Justamente por se tratar de um lugar idílico, sua descrição não é possível. Apenas em forma de fragmentos podemos ter um brevíssimo resplandecer desse tempo do qual se sente falta. E conforme escreve Gerd Bornheim,

O conflito entre a limitação do real e a infinitude do ideal é constitutivo do movimento romântico e permite compreender o sentido da exigência de unidade. Estrutura [...] a polaridade dentro da qual se movimenta a alma romântica, a fonte que a alimenta. A reconquista da unidade, do infinito sempre distante, determina a nostalgia romântica. Por isso mesmo, a nostalgia não é [...] um fenômeno primeiro do Romantismo. Primeiro é o sentido do infinito, do absoluto interior à alma humana condenada à sua finitude, e que extravasa no romântico sob forma de nostalgia, de Sehnsucht. (Borheim, 2008, p. 92)

\section{Referências Bibliográficas}

ADORNO, T. "Em memória de Eichendorff". In.: Adorno, T. Notas de Literatura I. Tradução e apresentação de Jorge M. B. de Almeida. São Paulo: Duas Cidades; Ed. 34, 2003.

AGAMBEN, G. "Os fantasmas de eros". In.: Agamben, G. Estâncias - a palavra e o fantasma na cultura ocidental. Tradução de Selvino José Assmann. Belo Horizonte: Editora UFMG, 2007.

${ }^{4}$ G. BORNHEIM. Filosofia do Romantismo. In: J. GUINSBURG. (org.) O Romantismo. São Paulo: Perspectiva, 2008, p. 92. 
BENJAMIN, W. Origem do drama barroco alemão. Tradução, apresentação e notas: Sergio Paulo Rouanet. São Paulo: Brasiliense, 1984.

BEUTIN, W., et al. História da literatura alemã. Das origens à atualidade. Apaginastantas, Edições Cosmos: Lisboa, 1993. BORNHEIM, G. Filosofia do Romantismo. In: GUINSBURG, J. (org.) O Romantismo. São Paulo: Perspectiva, 2008. EICHENDORFF, J. von. Werke in vier Bänden. Band 1 Gedichte. Köln: Verlag Luzia Prösdorf, 1965.

GINZBURG, J. Olhos turvos, mente errante - Elementos melancólicos em Lira dos Vinte Anos, de Álvares de Azevedo. 1997. 321p. Tese (Doutorado). Instituto de Letras, Universidade Federal do Rio Grande do Sul, Rio Grande do Sul: 1997. - Conceito de melancolia. Revista da Associação Psicanalítica de Porto Alegre, APPOA - Porto Alegre, v. 20, 2001.

KELH, M. R. O tempo e o cão. A atualidade das depressões. São Paulo: Boi Tempo, 2009.

KLIBANSKY, R.; PANOFSKY, E. \& SAXL, F. Saturno y la melancolia. Tradução de María Luisa Balseiro. Alianza Editorial, S.A. Madrid, 2012.

PRAZ, M. A carne, a morte e o diabo na literatura romântica. Campinas: Unicamp, 1996, p. 34.

SUGIYAMA, A. Wanderer unter dem Regenbogen - Die Rückenfigur Caspar David Friedrichs. 2007. 279 p. Tese (Doutorado). Frei Universität Berlin, Berlim: 2007.

VOLOBUEF, K. Frestas e arestas. A prosa de ficção do romantismo na Alemanha e no Brasil. São Paulo: Ed. Unesp, 1999. 
